\title{
Pengembangan Pasar Tenun Serat PT Retota Sakti Kabupaten Pekalongan, Jawa Tengah
}

\author{
Market Development of Woven Fiber at PT Retota Sakti, Pekalongan Regency, Central Java
}

\section{Hari Subagyo $^{1^{*}}$, M. Hasjim Bintoro ${ }^{2 \sharp}$ dan Parulian Hutagaol ${ }^{3 \sharp}$}

${ }_{1}^{1}$ PT BNI (Persero)Tbk

Jl. Jend. Sudirman, Kav. 1 Jakarta

${ }^{2}$ Departemen Budidaya Pertanian, Fakultas Pertanian, Institut Pertanian Bogor

${ }^{3}$ Departemen Ilmu Ekonomi, Fakultas Ekonomi dan Manajemen, Institut Pertanian Bogor

\#Jl. Kamper, Kampus IPB Darmaga, Bogor 16680

\begin{abstract}
ABSTRAK
Potensi industri tenun nasional sebagai salah satu Usaha Kecil Menengah (UKM) sejauh ini belum digali secara maksimal, karena belum diikuti dengan pengembangan sistem manajemen produksi. Untuk itu, PT Retota Sakti telah mendorong manajemen perusahaan meningkatkan kemampuan kreatif tenunnya disertai dengan penerapan strategi pemasaran yang tepat menurut perkembangan situasi persaingan di industri tenun. Tujuan penelitian ini adalah (1) Mengidentifikasi dan mengevaluasi posisi Pemasaran PT Retota Sakti berdasarkan faktor internal dan eksternal, serta (2) Menyusun strategi pemasaran yang tepat dalam mengembangkan usaha ke depan. Penelitian dianalisis secara deskriptif untuk menekankan aspek pemasaran, meliputi permintaan produk untuk memenuhi kebutuhan pasar; penawaran, yang memberikan gambaran tentang ketersediaan produk dalam proses usaha budidaya, serta faktor keseimbangan antara permintaan dan penawaran; harga, yang memberikan gambaran tentang mekanisme penetapan harga jual produk, hubungan antara harga jual dengan permintaan, dan faktor-faktor yang mempengaruhi harga jual produk; persaingan dan peluang pasar serta pemasaran produk. Kajian strategi pemasaran tenun serat dilakukan dengan menggunakan analisis Strengths, Weakness, Opportunities and Threats (SWOT) kuantitatif dan Quantitative Strategic Planning matrix (QSPM). Dari identifikasi faktor strategi, ada lima faktor kunci dari kekuatan dan empat faktor kunci kelemahan internal, sedangkan lingkungan eksternal ada lima faktor kunci peluang dan lima faktor kunci ancaman. Nilai IFE 2,842 dan EFE 2.530, kombinasi dari kedua nilai dalam matriks IE menunjukkan strategi pemasaran terletak pada kuadran lima, yaitu pertumbuhan dan stabilitas, melalui strategi penetrasi pasar, pengembangan produk dan pasar. Hasil analisis dengan matriks QSP diperoleh strategi meningkatkan kapasitas produksi.
\end{abstract}

Kata kunci: strategi pemasaran, industri tenun, tenun serat

\begin{abstract}
Potential weaving industry nationally as one of the SMEs so far have not unearthed the maximum due to the development of production management systems. Therefor, PT Retota Sakti has prompted company management to enhance the creative abilities tenunnya always accompanied by the application of more precise marketing strategies that correspond with the development of competition situation that occurred in the weaving industry. The purpose of this study was (1) Identify and evaluate the position of Marketing PT Retota Way by internal and external factors, and (2) Develop appropriate marketing strategies in developing future business. Analyzed in a descriptive study to emphasize the aspect of marketing, covering demand products to meet market needs; offer, which gives an overview about the availability of products in the process of cultivation and the balance of factors between demand and supply prices. To examine the marketing strategies carried out by quantitative SWOT analysis. The results of factor identification strategy, there are five key factors of internal strengths and weaknesses of
\end{abstract}

\footnotetext{
*) Korespondensi:

Jl. Jend. Sudirman Kav. 1, Jakarta; e-mail: arysubagyo@yahoo.co.id
} 
four key factors. While the external environment there are five key factors of opportunities and threats of five factors. IFE values 2.842 and $2.530 \mathrm{EFE}$ value, and also the combination of these two values in the matrix IE indicates that the marketing strategy lies in the quadrant of five, namely the growth and stability, where the strategies that can run the market penetration, product development and market. QSP matrix analysis results obtained with the most attractive strategy to be implemented is to increase production capacity.

Key words: marketing strategy, weaving industry, woven fiber

\section{PENDAHULUAN}

Tenun merupakan salah satu seni budaya kain tradisional lndonesia yang diproduksi di berbagai wilayah di seluruh Nusantara (Sumatera, Kalimantan, Bali, Sulawesi, Lombok, Sumbawa, Jawa Tengah). Tenun memiliki makna, nilai sejarah, dan teknik tinggi dari segi warna, motif, jenis bahan, serta benang yang digunakan dan tiap daerah memiliki ciri khas masing-masing.

Potensi industri tenun nasional sebagai salah satu usaha kecil menengah (UKM) sampai saat ini belum tergali secara maksimal akibat tidak berkembangnya sistem manajemen produksi. Padahal jika digarap serius tenun diprediksi bisa menyaingi produk batik yang sudah lebih dahulu menjadi ikon tekstil nasional. Saat ini para perajin tenun tradisional mulai enggan melanjutkan produksinya, karena merasa kalah bersaing dengan para perajin batik. Kurangnya minat para perajin itu, antara lain karena dalam produksinya memakan waktu cukup lama dan kurangnya apresiasi dari masyarakat terhadap tenun tradisional Indonesia.

Produk kerajinan khas Indonesia ini sudah dikenal hingga ke manca negara. Tidak hanya sekadar hasil seni dan budaya, produk kerajinan komoditas ekspor bernilai ekonomi tinggi. Untuk itu, para produsen atau perajin harus didorong untuk terus menggali dan mengembangkan produk kerajinan, sehingga tetap diminati pembeli.

PT Retota Sakti adalah salah satu perusahaan tenun lokal yang terletak di Pekalongan yang sepenuhnya dimiliki dan dikelola oleh orangorang 'pribumi' untuk permintaan ekspor. Sejak didirikan pada tahun 1981, yang merupakan cikal bakal dari sebuah usaha tenun serat, PT Retota Sakti mampu bertahan dan berkembang, meskipun harus bersaing dengan puluhan perusahaan tenun nasional yang sudah besar dan mapan.

Situasi persaingan yang ketat dan harus dihadapi oleh PT Retota Sakti dalam melawan para kompetitor, yang berasal dari sesama perusahaan sejenis lokal maupun global, telah mendorong pihak manajemen perusahaan meningkatkan kemampuan kreatif tenun dan disertai dengan penerapan strategi pemasaran lebih tepat menurut perkembangan situasi kompetisi yang terjadi di industri pertenunan. Namun demikian, suatu produk tidak akan berarti tanpa adanya pemasaran. Dalam kaitannya dengan merebut pasar, penerapan strategi pemasaran yang tepat sangat menunjang keberhasilan suatu produk di pasaran.

Penerapan strategi pemasaran harus mempertimbangkan faktor lingkungan perusahaan itu sendiri, baik eksternal maupun internal. Dalam mengembangkan strategi pemasaran, terdapat titik tolak yang dapat dikombinasikan, yaitu: (1) Strategi umum organisasi yang merupakan gambaran umum tujuan yang ingin dicapai dan pandangan dasar yang tumbuh sejak didirikannya organisasi; (2) Analisis situasi yang dapat dirumuskan sebagai suatu studi tentang faktor internal (kekuatan dan kelemahan yang terdapat di dalam organisasi) dan faktor eksternal (peluang dan ancaman yang timbul di luar organisasi).

Tujuan dari kajian ini: (1) Mengidentifikasi dan mengevaluasi posisi Pemasaran PT Retota Sakti berdasarkan faktor internal dan eksternal, serta (2) Menyusun strategi pemasaran yang tepat dalam mengembangkan usaha ke depan.

\section{METODOLOGI}

Lokasi penelitian adalah PT Retota Sakti yang terletak di Desa Wiradesa, Kabupaten Pekalongan, Jawa Tengah. Penelitian menggunakan gabungan data kualitatif maupun kuantitatif, baik yang diperoleh melalui pengumpulan data primer maupun sekunder, dengan cara:

1. Wawancara, dengan teknik wawancara mendalam (Indepth Interview), yaitu secara tatap muka dan melalui internet (online interview), dengan alat bantu kuesioner.

2. Observasi/pengamatan langsung sebagai tahapan penelitian dan penelitian utama.

3. Studi pustaka 
Dalam pengumpulan data, melibatkan nara sumber berikut:

1. Manajemen dan Direksi (President Director/ General Manager) Retota Sakti

2. Divisi Business Development Retota Sakti

3. Divisi Account Service Retota Sakti

4. Divisi Creative Retota Sakti

5. Divisi Promosi Retota Sakti

6. Divisi Facit \& HRD Retota Sakti

7. Departemen Public Relations Retota Sakti

Pengolahan dan analisis data dilakukan dengan dua model analisis, yaitu:

1. Analisis deskriptif, berupa proses penyusunan dan bentuk implementasi strategi pemasaran yang dilakukan PT Retota Sakti. Analisis data yang digunakan untuk keperluan ini meliputi tiga tahap berikut:

a. Description yang memaparkan fakta-fakta mengenai kondisi obyektif kasus yang diamati, dicatat dan dipaparkan berdasarkan pengalaman dan pengamatan secara empiris di lapangan.

b. Themes (analisis tema), sebagai bagian analisis data yang merujuk pada tema spesifik dengan cara mengumpulkan berbagai informasi yang didapatkan untuk kemudian dikelompokkan menjadi beberapa cluster atau kategori sejenis.

c. Assertions (penonjolan) merupakan langkah akhir yang meliputi pemahaman tentang data dan interpretasi. Hal ini dapat dilakukan melalui pandangan personal peneliti ataupun dengan bantuan teori dan kajian literatur.

2. Analisis strategi pemasaran berdasarkan Strengths, Weaknesses, Opportunities dan Threats (SWOT) Analysis, meliputi dua bentuk matriks, yaitu Internal Factor Evaluation (IFE) untuk mengetahui faktor internal perusahaan yang berkaitan dengan kekuatan dan kelemahan; dan External Factor Evaluation (EFE) untuk menganalisis faktor eksternal perusahaan yang menyangkut aspek makro ekonomi, kondisi sosial budaya, kebijakan pemerintah, perkembangan teknologi, hingga perkembangan industri, situasi pasar dan tingkat kompetisi.

Analisis data faktor lingkungan internal dan eksternal yang dimiliki PT Retota Sakti dilakukan melalui beberapa tahapan kerja berikut:

1. Menuliskan daftar kekuatan, kelemahan, peluang dan ancaman sebagai faktor internal dan eksternal pada kolom pertama di masingmasing matriks (IFE dan EFE).
2. Memberikan bobot tingkat urgensitas atributatribut kekuatan dan kelemahan maupun peluang dan ancaman tersebut dengan interval nilai 0,0 hingga 1,0 (tidak penting hingga sangat penting) pada kolom kedua, masingmasing total bobot yang diberikan harus sama dengan satu (Kinnear dan Taylor, 1991).

3. Memberikan rating atau peringkat berdasarkan skala 1-4 masing-masing atribut kekuatan dan kelemahan maupun peluang dan ancaman tersebut pada kolom ketiga. Rating atau peringkat berdasarkan skala 1-4 tersebut ditentukan dengan cara membandingkan fakta yang ada (kondisi obyektif) dengan kinerja ideal maupun kondisi ideal yang diharapkan.

4. Mengalikan bobot dengan rating atau peringkat untuk memperoleh skor terbobot. Skor yang diperoleh selanjutnya dijumlahkan untuk menggambarkan total skor terbobot di masingmasing matriks (IFE dan EFE).

Hasil gabungan total skor terbobot dari faktor-faktor internal dan eksternal menggambarkan 9 kuadran alternatif bentuk pengembangan strategi atas tiga bentuk strategi dasar, yaitu:

1. Strategi Pertumbuhan (Growth Strategy). Kuadran ini merupakan kondisi pertumbuhan perusahaan (kuadran 1, 2, 3, dan 5) atau upaya melakukan diversifikasi (kuadran 7 dan 8).

2. Strategi Stabilitas (Stability Strategy) adalah suatu bentuk strategi yang diterapkan tanpa mengubah arah strategi yang sedang berjalan atau sedang diterapkan (kuadran 4 dan 5).

3. Strategi Penciutan (retrenchment strategy) adalah usaha memperkecil atau mengurangi usaha yang dilakukan perusahaan (kuadran 3, 6 dan 9).

Dari analisis data yang dilakukan, dikembangkan model alternatif bentuk strategi pemasaran yang tepat bagi Advertising berdasarkan tipologi strategi yang ada, yaitu:

1. Strategi SO (Strengths-Opportunities)

Strategi memanfaatkan kekuatan internal perusahaan untuk meraih peluang-peluang yang ada di luar perusahaan.

2. Strategi WO (Weaknesses-Opportunities)

Strategi memperkecil berbagai kelemahan internal perusahaan untuk dapat tetap memanfaatkan peluang eksternal.

3. Strategi ST (Strengths-Threats)

Strategi memanfaatkan kekuatan internal perusahaan untuk mengatasi berbagai ancaman yang berasal dari luar perusahaan. 


\section{Strategi WT (Weaknesses-Threats)}

Strategi memperkecil berbagai kelemahan internal perusahaan dan menghindari berbagai ancaman yang berasal dari luar perusahaan.

Pada bagian akhir dari hasil analisis data yang telah dilakukan, selanjutnya tahap keputusan dalam daya saing, yaitu membahas stategi pemasaran yang telah dipilih dari hasil analisa dan membandingkannya dengan alternatif strategi lain dengan menggunakan Quantitative Strategies Planning Matrix (QSPM). Matriks tersebut menggunakan masukan dari tahap input dan tahap pemaduan untuk memutuskan strategi terbaik (David, 2006).

Matriks QSP terdiri atas empat komponen, antara lain (1) bobot, yang diberikan sama dengan yang ada pada matriks EFE dan IFE, (2) nilai daya tarik, (3) total nilai daya tarik, dan (4) jumlah total nilai daya tarik. Menurut David (2006) enam langkah yang diperlukan untuk mengembangkan matriks QSP adalah sebagai berikut:

1. Mendaftarkan peluang atau ancaman eksternal dan kekuatan atau kelemahan internal perusahaan dalam kolom kiri matriks QSP.

2. Memberikan bobot untuk setiap faktor eksternal dan internal, sesuai dengan yang dipakai dalam matriks IFE dan EFE.

3. Memeriksa tahap kedua (pemaduan) matriks dan mengidentifikasi strategi alternatif yang dapat dipertimbangkan perusahaan untuk diimplementasikan.

4. Menetapkan nilai daya tarik (AS) yang menunjukkan daya tarik relatif setiap strategi dalam alternatif set tertentu. Nilai daya tarik tersebut adalah 1 = tidak menarik, 2 = agak menarik, 3 = cukup menarik, $4=$ amat menarik.

5. Menghitung total nilai daya tarik dengan mengalikan bobot dengan nilai daya tarik.

6. Menghitung jumlah total nilai daya tarik. Jumlah ini mengungkapkan strategi mana yang paling menarik dalam setiap strategi. Semakin tinggi nilai menunjukkan strategi tersebut semakin baik.

\section{HASIL DAN PEMBAHASAN}

Didirikan pada tahun 1988, PT Retota Sakti bergerak di bidang manufaktur dan mengekspor produk-produk yang terbuat dari serat alami. Perusahaan memiliki berbagai macam produk, antara lain untuk penutup dinding \& karpet yang terbuat dari kenaf, serat pisang abaca \& Kelapa. Produk tenun dihasilkan oleh para pengrajin tenun melalui desain berkualitas tinggi dan dengan kesempurna finishing. Dengan jumlah tenaga kerja lebih dari 200 pekerja dan 20 staf yang bekerja.

Sejak tahun 1994, perusahaan telah mengekspor produknya ke Amerika Serikat dan Jepang dengan nilai yang baik. Dengan produk-produk eksklusif dan jaringan di pasar internasional, tujuannya adalah untuk memenuhi persyaratan pelanggan. Keberhasilannya ditunjukkan dalam hubungan jangka panjang dengan semua klien. Saat ini, PT Retota Sakti memproduksi untuk kliennya di Jepang, Taiwan, Korea, Meksiko dan Amerika Serikat.

Dilihat dari terminologi bisnisnya PT Retota Sakti merupakan jenis perusahaan keluarga Family Business Enterprise (FBE), yang dikelola oleh keluarga pendirinya. Pengelolaan dilakukan secara profesional dengan terbentuknya struktur organisasi yang baik serta jelas tugas dan wewenang dari masing-masing orang sebagaimana perusahaan pada umumnya, sehingga aktivitas usaha tetap dapat berjalan dengan baik.

Perusahaan dipimpin oleh pemilik perusahaan. Tugas dan wewenang yang dimiliki pimpinan, antara lain menetapkan kebijakan seluruh aktivitas usaha, menetapkan harga jual produk dan menentukan jumlah pegawai yang dibutuhkan. Pimpinan juga turut melakukan pengawasan mutu produk.

Terdapat beberapa bagian dalam perusahaan, yaitu bagian produksi, pemasaran, keuangan, personalia dan bagian umum, yang seluruhnya mendapat pengawasan dan bertanggungjawab langsung kepada direktur. Penerapan struktur organisasi pada PT Retota Sakti cukup sederhana, dengan garis komando dapat dilihat pengaruh pimpinan cukup mendominasi, terutama dalam pengambilan keputusan kegiatan usaha. Perusahaan didukung oleh orang-orang yang berpengalaman dan telah memiliki masa kerja 10-15 tahun, Sumber Daya Manusia (SDM) yang dipekerjakan dalam perusahaan \pm 200 orang, dimana setiap orang memiliki latar belakang pendidikan dan bidang keahlian yang berbeda.

\section{Teknis Produksi}

Sarana dan prasarana yang dimiliki perusahaan cukup lengkap, diantaranya:

1. Pabrik dan kantor produksi seluas $4.120 \mathrm{~m}^{2}$ berlokasi di Pekalongan, Jawa Tengah

2. Kendaraan operasional 5 buah 
3. Mesin-mesin produksi ATBM (alat tenun bukan mesin)

4. Ruang workshop

5. Investaris kantor lengkap

6. Gudang penyimpanan bahan baku dan gudang penyimpanan stok barang jadi dengan areal terpisah dengan pabrik (di depan pabrik).

Selain itu, lay-out mesin telah diatur dan disusun berdasarkan urutan kerja produksinya, sehingga cukup efisien, produktif dan berjalan dengan baik serta lancar. Untuk menghasilkan tenunan yang memiliki kekuatan mekanis tinggi diperlukan model konstruksi yang berbeda dengan aplikasi sandang pada umumnya (Syam dan Djafar, 2012).

Bahan yang digunakan dalam pembuatan produk tirai adalah serat pisang, benang kapas, enceng gondok dan rotan. Serat pisang dan benang katun merupakan bahan utama untuk dijadikan kain tenun. Serat pisang tersebut sebagai pakannya, sedangkan benang kapas menjadi lusinya. Enceng gondok berfungsi sebagai pengisi tenunan agar tampilan permukaan kain tenun lebih menarik. Rotan berfungsi sebagai penyangga agar tirai dapat terbentang, sehingga kain tenun tidak dapat terlipat. Pertimbangan dari penggunaan benang kapas karena memiliki tekstur lebih lembut dari serat rami yang agak kaku (Juhana et al, 2011).

Proses pembuatan produk tirai dari kain tenun serat pisang adalah proses pembuatan desain, penyiapan bahan, proses pertenunan, dan pembuatan produk. Pada proses pertenunan, kegiatan yang dilakukan meliputi tahap persiapan, diantaranya proses pengelosan/penggulungan benang, proses penggintiran, proses penyempurnaan merserisasi, proses pewarnaan, penghanian, penganjian dan pencucukan.

Proses penggintiran adalah proses perangkapan benang yang telah dikelos sebelumnya pada bobbin baru. Penggintiran dimaksudkan untuk mendapatkan benang yang lebih kuat lagi setelah dikanji. Untuk mendapatkan struktur kain yang jelas, twist atau putaran pada benang lusi bisa dilakukan dalam dua arah putaran kanan (Z) dan arah putaran kiri (S).

Proses merserisasi adalah proses penggelembungan serat (terutama serat kapas) dalam larutan Soda Kostik 25\% pada suhu ruangan. Dengan pengerjaan tersebut, kain dari serat kapas akan menunjukkan perubahan berikut:

1. Kain akan menjadi lebih pendek (mengkeret)

2. Kemampuan mulurnya meningkat

3. Kekuatan bertambah
4. Daya serap airnya meningkat

5. Kemampuan menyerap zat warna makin baik

6. Kilau kain akan makin tinggi

Proses penghanian adalah mengatur dan menggulung benang-benang lusi pada boom lusi atau boom tenun dengan sistem penggulungan sejajar. Tujuan proses penghanian agar proses selanjutnya berjalan dengan lancar. Oleh karena itu seluruh benang yang digulung harus sama panjang dan sama tegangannya.

Proses penganjian dilakukan dengan tujuan supaya pada saat dilakukan pertenunan, benang tidak mudah putus atau mudah kusut karena seringnya terkena gesekan dan mengalami ketegangan. Pencucukan adalah proses pemasukan benang lusi yang dilakukan secara dua tahap, yaitu proses pencucukan pada mata gun dan proses pencucukan pada sisir tenun.

Proses yang dilakukan saat pertenunan, kain tenun disusun oleh benang lusi dan benang pakan yang membuat silangan-silangan tertentu yang membentuk sudut $90^{\circ}$ satu sama lain. Proses pembuatan silangan-silangan disebut proses pertenunan. Agar proses pertenunan dapat dilaksanakan dengan baik, perlu diketahui gerakangerakan pokok yang terjadi pada proses tersebut.

Sesuai dengan urutan kerjanya, maka gerakan-gerakan tersebut adalah:

a. Pembukaan mulut lusi yaitu membuka benangbenang lusiagar membentuk celah yang disebut mulut lusi.

b. Peluncuran pakan, yaitu pemasukan atau peluncuran benang pakan menembus mulut lusi, sehingga benang lusi dengan pakan saling menyilang membentuk anyaman.

c. Pengetekan, yaitu merapatkan benang pakan yang baru diluncurkan kepada benang sebelumnya yang telah menganyam dengan benang lusi.

d. Penggulungan kain, yaitu menggulung kain sedikit demi sedikit sesuai dengan anyaman yang telah terjadi.

e. Penguluran lusi yaitu mengulur benang lusi dari gulungannya sedikit demi sedikit sesuai dengan kebutuhan proses pembentukan mulut lusi dan penyilangan benang berikutnya.

Dalam pemenuhan bahan baku produksi, hingga saat ini perusahaan tidak mengalami kesulitan yang berarti. Hal ini dikarenakan perusahaan telah menjalin hubungan yang baik dengan para pemasok, diantaranya:

1. PT Sentra Kebun Indonesia, untuk serat pisang abaca dengan volume pembelian sesuai kebutuhan atau Rp75-150 juta per bulan, tergantung 
kurs US\$ yang sedang berlaku. Hubungan sejak tahun 1995 dan hingga kini masih terjalin baik/menguntungkan kedua belah pihak.

2. PT Akindo Indonesia Trading, untuk serat rami dengan volume pembelian juga sesuai kebutuhan yang ada atau Rp50-100 juta per bulan. Hubungan terjalin sejak 1990 dan hingga kini masih berjalan baik/saling menguntungkan.

3. PT Swasembada Interbuana Ekantara, untuk eceng gondok dengan volume pembelian sesuai kebutuhan yang ada.

Cara pembayaran biasanya dilakukan secara kredit dengan jangka waktu hingga 1 minggu. Pembelian dilakukan kepada para pemasok lokal yang memang telah menjadi rekanan perusahaan sejak lama.

Kendala-kendala serta strategi perusahaan yang dihadapi saat ini, yaitu:

1. Pembayaran atau pembelian sebagian bahan baku menggunakan mata uang asing. Untuk itu, dikhawatirkan apabila kurs US\$ menguat akan menyulitkan perusahaan dalam penyediaan dana untuk menutupi ekuivalen dari nilai mata uang Rupiah terhadap Dolar US. Selain itu, perusahaan harus dapat menetapkan langkah-langkah yang tepat dalam penyediaan bahan baku produksi, sehingga keberadaan stok dapat terjaga dengan baik (tidak terjadi kelebihan maupun kekurangan, terutama dalam menjaga mutu bahan baku).

2. Mutu produk dan SDM dinilai masih kurang baik, mengingat belum adanya pelatihan dan pengembangan SDM dalam perbaikan produk dan SDM guna mempersiapkan diri menghadapi perubahan akibat adanya teknologi baru, desain pekerjaan, pelanggan baru atau pangsa pasar baru.

3. Tenaga pemasaran PT Retota Sakti saat ini belum memahami posisi perusahaan dalam pasar dan fokus bisnis, serta bagaimana secara individual memberikan kontribusi kesuksesan dan pertumbuhan yang belum optimal.

4. Promosi Produk belum dilakukan secara optimal oleh perusahaan, sehingga produk yang dihasilkan perusahaan belum dikenal oleh masyarakat luas.

\section{Identifikasi Faktor Internal dan Eksternal}

Hasil identifikasi faktor strategi internal (kekuatan dan kelemahan) dan eksternal (peluang dan ancaman) dievaluasi untuk menghasilkan alternatif strategi.

\section{Kekuatan}

a. Tenaga kerja

Secara konseptual, seorang pekerja dalam perusahaan yang memiliki kompetensi tinggi dilihat dari kultur masyarakat pekalongan yang secara turun temurun bergelut di bidang batik maupun tenun sehingga dapat meningkatkan efektivitas perusahaan dalam mencapai tujuan dan sasaran yang hendak diwujudkan.

b. Mutu produk

Mutu merupakan kesesuaian serangkaian karakteristik produk dengan standar yang ditetapkan perusahaan berdasarkan syarat, kebutuhan dan keinginan konsumen. Menghasilkan produk bermutu merupakan langkah awal dalam mengembangkan dan memelihara keunggulan produk dalam persaingan bisnis. Dalam hal ini, mutu produk tenun yang dihasilkan sudah sesuai dengan Standar Nasional Indonesia (SNI).

c. Fasilitas penunjang

Fasilitas yang dimiliki perusahaan cukup lengkap. Selain memiliki kantor produksi yang luas dan dilengkapi mesin-mesin produksi modern, juga gudang penyimpanan bahan baku dan stok barang yang terpisah. Selain itu, untuk memperlancar kegiatan perusahaan telah tersedia kendaraan operasional yang dapat digunakan setiap saat.

d. Loyalitas karyawan

Aset organisasi paling penting yang harus dimiliki oleh perusahaan dan sangat diperhatikan oleh manajemen adalah aset manusia dari organisasi tersebut. Bagaimanapun perusahaan memiliki keunggulan lainnya, perusahaan tidak akan dapat memaksimalkan produktivitas dan laba usahanya tanpa adanya komunitas karyawan kompeten yang berdedikasi tinggi terhadap terhadap keinginan perusahaan. Salah satu penyebab tingginya loyalitas karyawan adalah sistem kompensasi manajemen perusahaan yang baik, sehingga karyawan mendapat kepuasan kerja. Hal ini dibuktikan dengan turn over karyawan yang rendah.

e. Ketersediaan bahan baku

Dalam memenuhi bahan baku produksi, hingga kini perusahaan tidak mengalami kesulitan yang berarti, dikarenakan perusahaan telah menjalin hubungan baik dengan para pemasoknya. 


\section{Kelemahan}

a. Perusahaan keluarga

Sifatnya kurang formal karena ada keterlibatan pihak keluarga. Intervensi pihak keluarga terhadap kepemimpinan perusahaan tetap tinggi, meskipun sudah ada eksekutif profesional, sehingga dapat membingungkan anak buah. Keterlibatan anggota keluarga yang malas dan hanya menginginkan bagian keuntungan dari perusahaan keluarga akan dapat menimbulkan konflik dan dapat menghambat perkembangan perusahaan, bahkan dapat menyebabkan berhentinya perusahaan, sehingga akan menjadi kerugian.

b. Tenaga marketing

Pengalokasian sumber daya pemasaran produk merupakan aspek strategi pemasaran yang paling penting agar produk dapat lebih cepat berkembang dan dikenal masyarakat luas. Tenaga pemasaran PT Retota Sakti saat ini masih perlu memahami posisi perusahaan dalam pasar dan fokus bisnisnya, serta bagaimana secara individual memberikan kontribusi kesuksesan dan pertumbuhannya. Untuk itu, direktur/pemilik harus menekankan staf pemasaran untuk tetap memperhatikan pangsa pasar.

Staf pemasaran harus mampu membuat fungsi riset pasar, membuat dasar yang kuat untuk ide dan rencana pemasaran. Kegiatan riset rutin dan interaksi dengan peminat akan membentuk berbagai peluang. Interaksi antara staf pemasaran dengan konsumen sebenarnya bermakna sebuah proses penghantar pengetahuan dan pembelajaran. Konsumen memiliki berbagai cara untuk berhubungan dengan perusahaan sebagai usaha menyampaikan pendapat dan reaksinya. Jika perhatian pada makna kompetisi, sebaiknya staf pemasaran tahu benar siapa pesaing utamanya dan apa yang dapat diperbuat. Untuk itu Manajemen perusahaan harus paham bagaimana penilaian konsumen terhadap kompetisi itu.

c. Modal usaha

Selama ini permodalan untuk operasional perusahaan masih didominasi dari pinjaman bank. Tidak tertutup kemungkinan apabila kondisi perusahaan tidak stabil maka bank akan berpikir ulang untuk memberikan dana pinjaman, sementara persaingan dalam perkembangan usaha membutuhkan biaya tidak sedikit.

\section{d. Promosi}

Promosi merupakan ujung tombak dalam pemasaran produk, dengan kegiatan promosi produk dapat sampai ke konsumen, karena konsumen merupakan stakeholder utama yang menentukan suatu bisnis bisa survive atau tidak. Program pemasaran yang biasa dikembangkan oleh suatu perusahaan antara lain penggunaan iklan, penjualan pribadi, promosi penjualan dan hubungan masyarakat. Aktivitas promosi yang dilakukan PT Retota Sakti belum maksimal, yaitu hanya dalam penjualan produk.

\section{Peluang}

a. Kapasitas produksi

Kapasitas produksi yang terpakai perusahaan saat ini $70 \%$, dengan menggunakan satu unit mesin ATBM, perusahaan mampu memproduksi 10 unit hasil tenun per satu shift kerja yang lamanya sekitar delapan jam. Dari gambaran yang ada dapat dikatakan perusahaan masih mampu untuk meningkatkan hasil produksinya. Dengan mengoperasikan satu atau dua mesin lainnya secara bersamaan, secara otomatis tingkat produksinya akan bertambah.

b. Pangsa pasar

Pangsa pasar merupakan besarnya bagian pasar yang dikuasai suatu perusahaan. Pangsa pasar dapat dipecah-pecah menurut wilayah politis, kawasan geografis yang lebih besar, ukuran, pelanggan, tipe pelanggan dan teknologinya. Sampai saat ini pembeli dominan tercatat ada dua perusahaan besar, yaitu Conrad Inc, Asakawa \& Co dan PT Karseni. Dari data di atas dapat dikatakan bahwa peluang untuk mengembangkan produksi masih cukup besar. Bila perusahaan mampu memenangkan persaingan dengan industri sejenis, kesempatan merebut pasar masih terbuka lebar.

c. Kemajuan Teknologi

Salah satu sumber utama perubahan, yaitu teknologi, karena akan melahirkan penemuanpenemuan baru. Dalam kaitannya dengan proses produksi, perubahan dapat memengaruhi bahan baku, operasi dan produk perusahaan. Namun demikian, perubahan teknologi dapat memberikan peluang besar untuk peningkatan hasil dan tujuan perusahaan. Teknologi yang terus berkembang memberikan kontribusi besar bagi keberadaan perusahaan. Faktor teknologi turut membantu 
perusahaan dalam menjalankan kegiatan operasional sehari-hari, seperti mesin-mesin yang dapat membantu percepatan dan mutu produksi. Peluang yang tidak terbatas dari perubahan teknologi menjadi tantangan bagi perusahaan untuk mampu menghasilkan produk yang lebih baik dan sesuai dengan keinginan konsumen tanpa mengesampingkan perhatian pada lingkungan hidup, kesehatan dan keselamatan konsumen. Dengan begitu, tidak hanya dapat meluas pangsa pasar, dukungan dan loyalitas konsumen terhadap produk perusahaan akan dapat ditingkatkan.

d. Demografi dan Sosial

Arus informasi yang semakin cepat dan global akibat berkembangnya teknologi informasi menyebabkan perubahan pola konsumsi masyarakat. Dalam hal ini, masyarakat lebih mengutamakan hal-hal yang praktis.

e. Diversifikasi Produk

Perubahan dalam selera konsumen, teknologi dan persaingan yang cepat, membuat perusahaan harus mengembangkan arus produk secara terus menerus (Kotler dan Amstrong, 2001). Pengembangan produk baru atau modifikasi produk merupakan peluang bagi PT Retota Sakti untuk menghadapi persaingan usaha tenun.

\section{Ancaman}

a. Keberadaan perusahaan sejenis

Perusahaan yang bergerak dalam industri tenun, khususnya tenun serat tidak cukup banyak ( \pm 10 perusahaan). Kondisi persaingan dalam jenis bidang usaha tersebut dinilai kompetitif maka setiap perusahaan harus memiliki ciri khas, serta keunikan sendiri dan mampu menawarkan sesuatu berbeda kepada konsumen, diantaranya melakukan inovasi baru agar dapat mengatasi persaingan tersebut dan corak yang berbeda.

b. Daya tawar menawar

Semakin banyaknya perusahaan yang bergerak dalam produk sejenis menyebabkan persaingan semakin ketat, baik dalam merebut pasar maupun dalam persaingan dalam pemenuhan bahan baku. Oleh karena itu, pasokan bahan baku memiliki peran penting dalam tingkat persaingan perusahaan, sehingga bargaining position para pemasok bahan baku semakin tinggi dan strategik. Begitupula dengan beragam produk yang dihasilkan, akan memengaruhi harga yang ditawarkan kepada konsumen yang memiliki kekuatan penawar- an. Kekuatan tawar menawar konsumen tersebut harus menjadi pertimbangan agar perusahaan mampu mengatasi persaingan.

c. Perusahaan pendatang baru

Menurut data Cita Tenun Indonesia, saat ini ada sekitar 3.000-4.000 industri Tenun yang bergerak di hulu hingga hilir. Dengan semakin maju teknologi tidak menutup kemungkinan melahirkan perusahaan baru dengan menggunakan teknologi lebih modern dan dapat mempercepat produksi dengan beragam motif

d. Kondisi ekonomi dan politik

Kondisi perekonomian suatu negara dapat mempengaruhi kinerja suatu industri. Faktor ekonomi suatu negara akan bercermin pada strategi dan langkah perusahaan, kesehatan suatu industri turut memengaruhi kesehatan negara. Hal ini berarti antara negara dan perusahaan terjadi hubungan yang saling bersinergi. Salah satunya, kenaikan harga minyak dunia di pasar internasional memengaruhi harga bahan baku. Ketergantungan impor menyebabkan industri tenun sulit bersaing. Implikasinya secara langsung terhadap harga pembelian yang berpengaruh pada harga penjualan PT Retota Sakti.

e. Kebijakan pemerintah

Pemberlakuan Kesepakatan Perdagangan Bebas (Free Trade Agreement atau FTA), khususnya di Association of South East Asia nation (ASEAN), telah membuat perusahaan-perusahaan mengubah strategi pabrikannya. Untuk itu perusahaan diperlukan perbaikan mutu produk dan harga yang kompetitif untuk dapat bersaing di pasar bebas.

\section{Perumusan Strategi Pemasaran}

Analisis matriks IFE dan EFE dilakukan terhadap lingkungan internal dan eksternal perusahaan, sehingga diperoleh faktor-faktor kunci yang termasuk ke dalam kekuatan, kelemahan, peluang dan ancamannya. Skor yang diperoleh dari matriks ini menunjukkan kemampuan perusahaan dalam memanfaatkan kekuatan dan mengatasi kelemahan yang dimiliki, serta menunjukkan kemampuan dalam meraih peluang dan mengatasi ancaman eksternalnya.

\section{Analisis Matriks IFE}

Faktor yang menjadi kekuatan utama PT Retota Sakti adalah tenaga kerja dengan bobot 0,132 dan rating 4,000, sehingga diperoleh skor 0,528. Kelemahan utama PT Retota Sakti adalah 
kegiatan promosi dengan bobot 0,090 dengan rating 1,500, sehingga diperoleh skor 0,135 dan tenaga marketing $(0,173)$. Secara lebih rinci hasil perhitungan faktor strategi internal dapat dilihat pada Tabel 1.

Dari hasil analisis faktor internal didapatkan total skor 2,842. Nilai tersebut di atas rataan 2,50, menunjukkan posisi internal perusahaan cukup kuat, yaitu memiliki kemampuan di atas rataan dalam memanfaatkan kekuatan dan mengantisipasi kelemahan internal.

\section{Análisis Matriks EFE}

Kapasitas produksi merupakan peluang utama dengan bobot 0,110 dan rating 4,000, sehingga diperoleh skor 0,441. Sementara itu, faktor yang menjadi ancaman utama perusahaan adalah keberadaan perusahaan sejenis dengan bobot 0,105 dan rating 1,000, sehingga diperoleh skor 0,105. Perusahaan pendatang baru, dimana perusahaan yang akan bergerak dalam bidang sama (skor 0,124) merupakan ancaman lain yang dapat memengaruhi perkembangan perusahaan dan perlu mendapat perhatian (Tabel 2).

Dari hasil analisis faktor strategi eksternal didapatkan total skor 2,530. Nilai ini berada di atas rataan 2,50, yaitu perusahaan memiliki strategi efektif yang dapat memanfaatkan peluang dan meminimalkan ancaman/pengaruh negatif dari lingkungan eksternalnya.

\section{Analisis Matriks IE}

Penentuan posisi strategi perusahaan dalam matriks IE didasarkan pada hasil total nilai matriks IFE yang diberi bobot pada sumbu $x$ dan total nilai matriks EFE pada sumbu y (David, 2006). Total nilai matriks IFE 2,842 dan nilai matriks EFE 2,530 maka posisi PT Retota Sakti terletak pada sel V (Gambar 1) dengan strategi yang sesuai adalah penetrasi pasar dan pengembangan produk. Hasil ini selanjutnya akan digunakan untuk merumuskan alternatif strategi dengan menggunakan matriks SWOT.

\section{Analisis Matriks SWOT}

Pengembangan strategi pada matriks dilakukan sesuai hasil matriks IE, posisi perusahaan terletak pada kuadran V. Pencocokan faktor strategi internal dan eksternal dilakukan dalam lingkup strategi penetrasi pasar dan pengembangan produk. (Rangkuti, 2005).

Tabel 1. Matriks IFE

\begin{tabular}{lccc}
\hline \multicolumn{1}{c}{ FAKTOR INTERNAL } & Bobot (a) & Rating (b) & Skor (axb) \\
\hline A. Tenaga kerja & 0,132 & 4,000 & 0,528 \\
B. Mutu produk & 0,130 & 4,000 & 0,521 \\
C. Fasilitas penunjang & 0,092 & 3,250 & 0,299 \\
D. Loyalitas karyawan & 0,118 & 3,500 & 0,413 \\
E. Ketersediaan bahan baku & 0,106 & 3,750 & 0,397 \\
F. Perusahaan keluarga & 0,106 & 1,750 & 0,185 \\
G. Tenaga marketing & 0,099 & 1,750 & 0,173 \\
H. Modal usaha & 0,127 & 1,500 & 0,190 \\
I. Promosi & 0,090 & 1,500 & 0,135 \\
\hline \multicolumn{1}{c}{ TOTAL } & 1,000 & 2,842 \\
\hline
\end{tabular}

Tabel 2. Matriks EFE

\begin{tabular}{lccc}
\hline \multicolumn{1}{c}{ FAKTOR EKSTERNAL } & Bobot (a) & Rating (b) & Skor (axb) \\
\hline A. Kapasitas produksi & 0,110 & 4,000 & 0,441 \\
B. Pangsa pasar & 0,089 & 3,500 & 0,312 \\
C. Kemajuan teknologi & 0,117 & 3,750 & 0,439 \\
D. Demografi dan sosial & 0,084 & 3,500 & 0,293 \\
E. Diversifikasi produk & 0,098 & 3,500 & 0,342 \\
F. Keberadaan perusahaan sejenis & 0,105 & 1,000 & 0,105 \\
G. Daya tawar menawar & 0,112 & 1,750 & 0,195 \\
H. Perusahaan pendatang baru & 0,099 & 1,250 & 0,124 \\
I. Kondisi ekonomi dan politik & 0,096 & 1,250 & 0,120 \\
J. Kebijakan pemerintah & 0,091 & 1,750 & 0,159 \\
\hline \multicolumn{1}{c}{ TOTAL } & 1,000 & \multicolumn{2}{c}{} \\
\hline
\end{tabular}




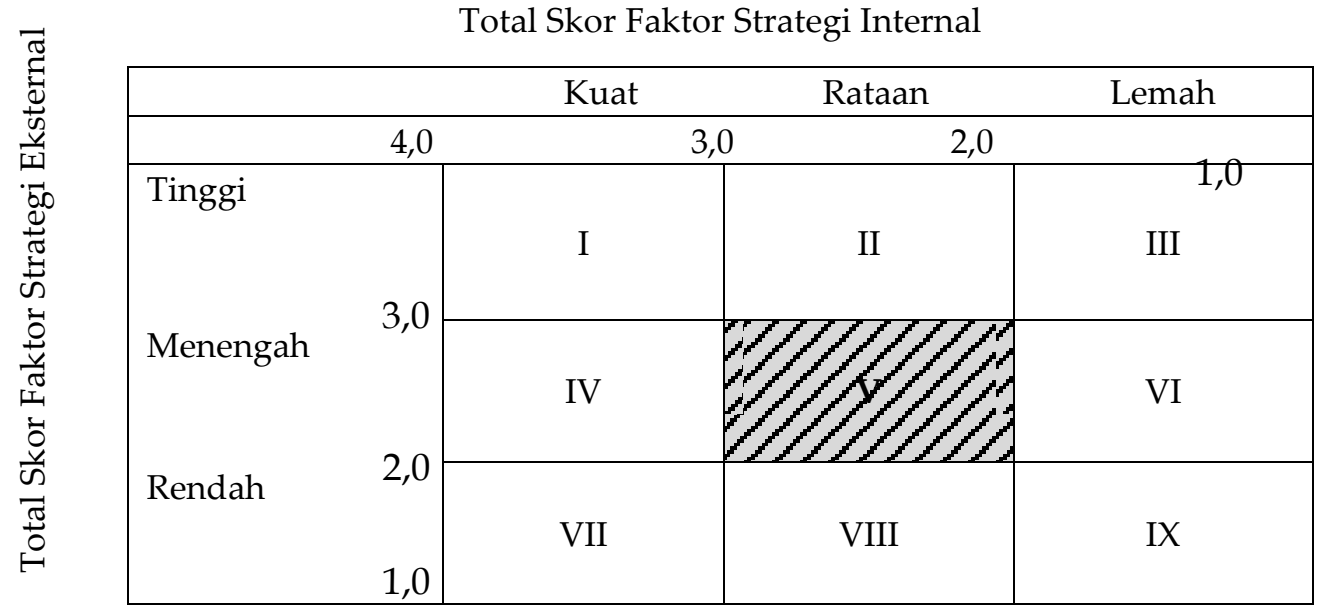

Gambar 1. Matriks IE PT Retota Sakti

Berdasarkan hasil analisis matriks IFE dan EFE dapat disusun matriks SWOT yang akan menghasilkan empat tipe strategi yang dapat dilakukan, yaitu strategi S-O, W-O, S-T dan W-T. Hasil analisis SWOT dapat dilihat pada Tabel 3.

Strategi kekuatan - peluang (SO)

1) Meningkatkan kapasitas produksi (S1, S3, S5: $\mathrm{O} 1, \mathrm{O} 2, \mathrm{O} 3, \mathrm{O} 5)$

Kekuatan dalam hal tenaga kerja, fasilitas penunjang dan ketersediaan bahan baku dengan dukungan oleh kemajuan teknologi dapat dimanfaatkan oleh perusahaan untuk melakukan peningkatan jumlah produksi yang dihasilkan dalam rangka mengembangkan usaha, dan memenuhi pangsa pasar yang masih terbuka.

2) Mengembangkan produk baru (S1, S2, S3: O1, O3, O4, O5).

Dalam menghadapi persaingan usaha yang semakin ketat, pengembangan produk baru menjadi salah satu alternatif yang dapat dilakukan perusahaan. Dengan memiliki tenaga kerja yang ahli di bidangnya serta fasilitas penunjang yang baik dan modern, memungkinkan untuk mengembangkan produk-produk olahan baru, juga untuk memperpanjang daur hidup produk.

Strategi kelemahan - peluang (WO)

1) Meningkatkan kegiatan promosi (W2, W3: $\mathrm{O} 2$,

O5)

Kegiatan promosi merupakan suatu usaha dari pemasar dalam menginformasikan dan memengaruhi orang atau pihak lain sehingga tertarik untuk melakukan transaksi atau pertukaran produk barang yang dipasarkannya. Meningkatkan mutu dan kinerja tenaga marketing PT Retota Sakti, sehingga bisa memanfaatkan peluang pangsa pasar yang besar. Kreativitas perusahaan dengan modal terbatas untuk membuat diversifikasi produk dapat menarik pangsa pasar yang baru.

2) Menetapkan harga kompetitif dan potongan harga (W2, W3, W4: O1, O2, O4)

Penyesuaian harga disebut diskon atau pengurangan harga menurut Kotler dan Amstrong (2001), yaitu tindakan perusahaan menyesuaikan harga dasar untuk memberikan penghargaan pada pelanggan atas reaksireaksi tertentu. Masyarakat sekarang ini lebih tertarik dengan produk berlabel diskon dibandingkan harga normal walaupun bedanya hanya sedikit. Hal ini merupakan peluang untuk meningkatkan pangsa pasar pada segmen pasar tertentu.

Strategi kekuatan - ancaman (ST)

1) Mempertahankan dan meningkatkan mutu produk (S1, S2, S3, S4: T1, T2, T3)

Persaingan usaha dalam bidang industri Tenun khususnya Tenun Serat yang semakin ketat, baik dari perusahaan yang sudah ada maupun dengan perusahaan pendatang baru dalam merebut pasar menuntut perusahaan menjaga dan meningkatkan mutu produknya, diantaranya dengan menghasilkan produk sesuai standar yang berlaku di Indonesia (SNI), selain itu juga untuk meningkatkan daya tawar produk di pasar.

Strategi kelemahan - ancaman (WT)

1) Meningkatkan hubungan dengan para stakeholder (W1, W3: T2, T4, T5)

Kepemilikan yang merupakan perusahaan keluarga dan modal usaha yang masih mengandalkan kredit dari bank diharapkan dapat diatasi dengan meningkatkan kemitraan 
dengan para stakeholder (misal, kerjasama dengan pemasok tentang pengadaan bahan baku untuk menjamin ketersediaan dan kelangsungan produksi dan menekan biaya operasional, serta bank BUMN untuk mendapatkan tambahan modal guna pengembangan usaha).

2) Meningkatkan mutu SDM (W1,W2,W4: T1,T3)

Meningkatkan mutu SDM melalui pelatihan dan pengembangan. pelatihan (training) terfokus pada penyediaan keahlian khusus bagi para karyawan atau membantu membenahi kelemahan kinerjanya, sedangkan pengembangan (development) membantu para karyawan untuk mempersiapkan diri menghadapi perubahan di pekerjaannya akibat adanya teknologi baru, desain pekerjaan, pelanggan baru atau pangsa pasar baru.

Kesuksesan perusahaan keluarga bergantung pada kemampuan mengelola kompetensi yang beragam antara pemilik, manajer, karyawan dan anggota keluarga, serta mengatasi konflik yang terjadi pada saat memilih anggota-anggota keluarga dan orang-orang yang kompeten untuk menjalankan perusahaan.

\section{Analisis Matriks QSP}

Untuk mengevaluasi dan menganalisis secara obyektif alternatif strategi yang dihasilkan dari matriks SWOT sekaligus menentukan strategi prioritas dilakukan dengan matriks QSP. Alternatif-alternatif strategi dimaksud adalah:

a. Meningkatkan kapasitas produksi

b. Mengembangkan produk baru

c. Meningkatkan kegiatan promosi

d. Menetapkan harga kompetitif dan potongan harga

e. Mempertahankan dan meningkatkan mutu produk

f. Meningkatkan hubungan dengan stakeholder

g. Meningkatkan mutu SDM

Berdasarkan hasil perhitungan dalam matriks QSP, diperoleh strategi yang paling tepat untuk diimplementasikan adalah meningkatkan kapasitas produksi (TAS 5,218). Untuk lebih jelas tentang urutan prioritas strategi dari hasil matriks QSP dapat dilihat pada Tabel 4.

Peningkatan kapasitas produksi dapat dilakukan melalui: (1) Strategi pertama, trading based, yakni menunjuk distributor lokal di negaranegara tujuan ekspor. Kerjasama tersebut sangat sederhana, karena sebatas aktivitas jual-beli saja; (2) Strategi kedua, marketing based. PT Retota Sakti membangun kantor perwakilan di setiap negara tujuan yang dari hasil survei internal berpotensi bagi pengembangan produk ekspornya.

Tabel 3. Matriks SWOT PT Retota Sakti

\begin{tabular}{|c|c|c|}
\hline Faktor Eksternal & $\begin{array}{l}\quad \text { Kekuatan (S) } \\
\text { 1. Tenaga kerja } \\
\text { 2. Mutu produk } \\
\text { 3. Fasilitas penunjang } \\
\text { 4. Loyalitas karyawan } \\
\text { 5. Ketersediaan bahan } \\
\text { baku }\end{array}$ & $\begin{array}{l}\text { Kelemahan }(\mathbf{W}) \\
\text { 1. Perusahaan keluarga } \\
\text { 2. Tenaga marketing } \\
\text { 3. Modal usaha } \\
\text { 4. Promosi }\end{array}$ \\
\hline $\begin{array}{l}\quad \text { Peluang (O) } \\
\text { 1. Kapasitas produksi } \\
\text { 2. Pangsa pasar } \\
\text { 3. Kemajuan teknologi } \\
\text { 4. Demografi dan sosial } \\
\text { 5. Diversifikasi produk }\end{array}$ & \begin{tabular}{l}
\multicolumn{1}{c}{ Strategi S-O } \\
a. Meningkatkan kapasitas \\
produksi (S1, S3, S5: O1, \\
O2, O3, O5) \\
b. Mengembangkan \\
produk baru (S1, S2, S3: \\
O1, O3, O4, O5).
\end{tabular} & \begin{tabular}{l}
\multicolumn{1}{c}{ Strategi W-O } \\
a. Meningkatkan kegiatan \\
promosi (W2, W3: O2, O5) \\
b. Menetapkan harga \\
kompetitif dan potongan \\
harga (W2, W3, W4: O1, O2, \\
O4)
\end{tabular} \\
\hline $\begin{array}{l}\quad \text { Ancaman (T) } \\
\text { 1. Keberadaan perusahaan } \\
\text { sejenis } \\
\text { 2. Daya tawar menawar } \\
\text { 3. Perusahaan pendatang baru } \\
\text { 4. Kondisi ekonomi dan politik } \\
\text { 5. Kebijakan pemerintah }\end{array}$ & \begin{tabular}{l}
\multicolumn{1}{c}{ Strategi S-T } \\
a. Mempertahankan dan \\
meningkatkan mutu \\
produk (S1, S2, S3, S4: \\
T1, T2, T3)
\end{tabular} & \begin{tabular}{l}
\multicolumn{1}{c}{ Strategi W-T } \\
a. Meningkatkan hubungan \\
dengan para stakeholder (W1, \\
W3: T2, T4, T5) \\
b. Meningkatkan mutu SDM \\
(W1, W2, W4: T1, T3)
\end{tabular} \\
\hline
\end{tabular}


Tabel 4. Urutan prioritas strategi dari matriks QSP pada PT Retota Sakti

\begin{tabular}{lcc}
\hline \multicolumn{1}{c}{ Alternatif strategi } & $\begin{array}{c}\text { Total nilai } \\
\text { daya tarik }\end{array}$ & $\begin{array}{c}\text { Urutan } \\
\text { prioritas }\end{array}$ \\
\hline $\begin{array}{l}\text { Meningkatkan kapasitas } \\
\text { produksi } \\
\text { Mengembangkan produk } \\
\text { baru }\end{array}$ & 5,218 & 1 \\
$\begin{array}{l}\text { Meningkatkan kegiatan } \\
\text { promosi }\end{array}$ & 5,099 & 2 \\
$\begin{array}{l}\text { Menetapkan harga } \\
\text { kompetitif dan potongan } \\
\text { harga, serta sistem } \\
\text { pembayaran }\end{array}$ & 4,319 & 5 \\
$\begin{array}{l}\text { Mempertahankan dan } \\
\text { meningkatkan mutu produk }\end{array}$ & 5,051 & 4 \\
$\begin{array}{l}\text { Meningkatkan hubungan } \\
\text { dengan para stakeholder }\end{array}$ & 4,005 & 7 \\
\begin{tabular}{l} 
Meningkatkan mutu SDM \\
\hline
\end{tabular} & 5,074 & 3 \\
\hline
\end{tabular}

\section{Implementasi Strategi}

Berdasarkan hasil penelitian dibuat implikasi manajerial yang harus dilakukan oleh manajemen PT Retota Sakti dikaitkan dengan bauran pemasaran yang terdiri atas product, price, place, promotion dan people.

Implikasi manajerial berkaitan dengan bauran pemasaran product adalah memberikan masukan kepada PT Retota Sakti untuk memperbaiki mutu dengan produk bermutu merupakan langkah awal mengembangkan dan memelihara keunggulan produk dalam persaingan bisnis dan memanfaatkan teknologi untuk meningkatkan mutu produk dan konsisten dengan mempertahankan produktifitas agar diterima pasar.

Implikasi manajerial yang dapat dilakukan oleh PT Retota Sakti berkaitan dengan bauran pemasaran price adalah memberikan harga lebih rendah dibandingkan dengan pesaing dan memberikan potongan harga kepada konsumen yang memesan dalam jumlah besar juga potongan harga pada hari-hari tertentu, seperti tahun baru, menyambut puasa dan lebaran. Implikasi manajerial yang dapat dilakukan oleh PT Retota Sakti berkaitan dengan bauran pemasaran place adalah selalu berusaha membuat ruangan yang bersih dan nyaman untuk konsumen, menjamin tersedianya produk dalam jumlah yang cukup dan variatif, serta dapat memperpanjang waktu pelayanan untuk hari-hari tertentu saat ramai pengunjung.

Implikasi manajerial yang dapat dilakukan oleh PT Retota Sakti berkaitan dengan bauran pemasaran promotion adalah cara menginformasikan tentang suatu produk langsung ke konsumen atau dengan bentuk brosur yang menarik; Memperluas jaringan pemasaran dengan melakukan penetrasi pasar, misal membuat ritel gerai dan usaha waralaba; Perluasan jaringan pemasaran dengan menjalin pola kemitraan dengan IKM yang bergerak di bidang industri kreatif dan pengenalan label produk untuk menjaga eksistensi industri kecil; Pihak perusahaan harus cermat dalam mengelola konsumen loyal dengan cara memperlakukan konsumen dengan layak, menjalin hubungan yang dekat dengan pelanggan, mengukur atau mengelola kepuasan pelanggan dan memberikan ekstra (souvenir, penjelasan produk atau contoh), serta mengadakan event-event yang dapat meningkatkan ekuitas produk, khususnya serat tenun; Implikasi manajerial yang berkaitan dengan bauran pemasaran people (SDM) adalah komitmen manajemen dan karyawan untuk melaksanakan prinsip jual-beli dan pelayanan kepada pelanggan dengan baik, mengembangkan dan memperbaiki standar mutu produk, serta kinerja pelayanan juga melatih karyawan agar lebih terampil. Untuk itu, pengukuran mutu produk dan pelayanan (service quality) secara berkala akan membantu manajemen PT Retota Sakti untuk mengetahui kebutuhan masyarakat dan konsumen dan mengelola service delivery secara efektif.

\section{KESIMPULAN}

Berdasarkan hasil penelitian dapat disimpulkan bahwa PT Retora Sakti harus melakukan hal berikut: Meningkatkan kapasitas produksi; Mengembangkan produk baru atau inovasi dalam produk; Meningkatkan mutu SDM; Mempertahankan dan meningkatkan mutu produk; Meningkatkan kegiatan promosi; Menetapkan harga kompetitif dan potongan harga, serta sistem pembayaran; dan Meningkatkan hubungan dengan para stakeholder. Posisi pemasaran PT Retora Sakti pada sel V, dengan strategi yang sesuai adalah penetrasi pasar dan pengembangan produk.

Penerapan strategi yang dapat dilakukan PT Ratori Sakti adalah meningkatkan kapasitas produksi dan mengembangkan produk baru. Strategi dapat difokuskan pada harga, produksi, pemasaran dan SDM. 


\section{DAFTAR PUSTAKA}

David, F.R. 2006. Manajemen Strategi. Jakarta (Terjemahan). PT. Prenhallindo.

Juhana, A., M. Hubeis dan N.H. Pandjaitan. 2011. Prospek Ekonomi dan Strategi Pengembangan Kapas Rami Sebagai Bahan Baku Alternatif Industri Tekstil Skala Usaha Kecil (Kasus Koppontren Darussalam, GarutJawa Barat). J. Manajemen IKM, 6(2) : 111116).

Kinnear, T.C. and J.R. Taylor. 1991. Marketing Research, an Applied Approach. Fourth Edition. New York. Mc Graw Hill.
Kotler, P. dan G. Amstrong. 2001. Prinsip-Prinsip Pemasaran. Jakarta. Erlangga..

Rangkuti, F. 2005. Analisis SWOT Teknik Membedah Kasus Bisnis. Penerbit PT. Gramedia Pustaka Utama, Jakarta.

Syam, R., dan Z. Djafar. 2012. Analisis Sifat Mekanis Tenunan Serat Rami Jenis Basket Tipe S 3/12 Dengan Matriks Epoksi Resin (Kekuatan Bending). Prosiding Hasil Pertanian Fakultas Teknik. Vol 6, Desember 2012: 1-12. 